\title{
Women's Labour Supply in Nigeria: An Econometric Analysis
}

\author{
Akin Iwayemi ${ }^{1}$, M.O. Olusoji ${ }^{2 *}$ \\ ${ }^{1}$ Department of Economics, University of Ibadan, Ibadan, Nigeria, and Centre for Econometric and Allied \\ Research (CEAR), Ibadan, Nigeria \\ ${ }^{2}$ Centre for Management Development, Lagos, Nigeria
}

\begin{abstract}
This paper examines two key issues central to the analysis of labour markets in Nigeria and other multi-ethnic and multi-cultural developing countries: women's labour force participation and the hours they work. Using a sample survey based on the six geopolitical zones in Nigeria, the study estimates labour participation rates using a logit model and hours worked using Heckman two-stage procedure. The results of the analysis show that women's labour force participation rates depend on age, education, ethnic origin, respondent's income, religion and relationship to the household head. The results confirm the impact of cultural and spatial heterogeneity on the responses of women to employment opportunities in the labour market.
\end{abstract}

Keywords: Women labour, geopolitical zones, formal sector, informal sector, Nigeria

JEL classification: J16; J21; J29

\section{Introduction}

The issue of low labour force participation rates for women has been of great policy concern in subSaharan Africa, especially since the sharp decline in the living standards of most families consequent to the adverse impact of International Monetary Fund (IMF) and World Bank-driven structural adjustment programmes and subsequent economic policy reforms adopted in the last two decades. A key explanation for the policy concern is the need to address the significant adverse impact of low labour force participation on women's income earning capacity, a development that has exacerbated their poverty status and vulnerability in society.

Increased participation of women in economic activity and the labour force has also been a key policy objective in Nigeria for nearly two decades. ${ }^{i}$ Yet, the percentage of women in the total labour force hardly changed between 1970 and 2000, at about 45\% (World Bank 2002). This stagnation in women's participation rate must be viewed against the significant shift in the structure of the labour force from the dominance of the agricultural sector to services. Also of significance are the enormous spatial and cultural diversities in the participation rates (Olusoji 2004). ${ }^{\text {ii }}$

It is widely recognized that full integration of women into the economy and higher labour supply are central to improving their relative economic conditions and optimal development of the growth potentials of the economy. Designing and implementing labour market policies and programmes that promote increased employment opportunities for women is central to reversing the sharp deterioration in the wellbeing of the majority of households in the region. Consequently, more up-to-date empirical analyses of the factors that influence women's labour supply are essential to sound policy design and implementation.

A number of characteristics make the analysis of women's labour supply issues more complex in Nigeria and other developing countries than in the developed economies. These include the essentially dual economic structure dominated by the rural sector, characterized by highly segmented labour markets, which are largely spatially immobile and socially and culturally heterogeneous. It is pertinent to understand how these fundamental factors predispose women to offer their services in the labour market and for how long.

There is a considerable gap in the economic and econometric literature on women's labour supply issues in Nigeria. ${ }^{\text {iii }}$ Expanding on the only two previous econometric analyses (Okojie 1981; Urama and Obinna 2003), this study provides a quantitative analysis of the factors that influence whether and how much women work for pay by reflecting more realistically the role of spatial, cultural, ethnic, religious and economic diversities. Applying a household economic model framework we use cross-sectional data derived from a sample survey of the six geopolitical zones in the country to test alternative hypotheses about the two key aspects of women's labour supply in Nigeria. Our results provide insights into policy formulation and implementation concerning this important social and economic problem. Following the introduction is the literature review and theoretical framework in section 2.

\footnotetext{
* The corresponding author, Dr. (Mrs.) M.O. Olusoji is a staff of Centre for Management Development(CMD), Management Village, Shangisha, P.M.B. 21578, Ikeja Post Office, Lagos

The African Economic Research Consortium (AERC), Nairobi, Kenya, provided the financial support for this research.
} 
Section 3 presents the model specification and methodology while section 4 contains analysis of results. Section 5 concludes the paper.

\subsection{Literature Review}

\section{Literature Review And Theoretical Framework}

In this section we briefly review the underlying theory explaining women's labour force participation and labour supply with focus on developing countries. The selected review of the literature on intra-household resource allocation is dictated by the scope of this study. ${ }^{\mathrm{iv}}$

Basic neoclassical theory has been found to be inadequate for explaining labour market conditions in developing countries. The need to address this issue and, more importantly, to have a better grasp of intra-household resource allocation problems and their implications for social policy explains the widening of the orthodox Beckerian household framework of unitary (single utility) model to incorporate collective bargaining and noncooperative models of the household. (Haddad et al. 1997). An important feature of the new household model is its recognition of the fact that the labour supply of household members, especially the wife, is associated with a host of non-market decisions, including fertility, marriage and human capital.

Joll et al. (1993) examine the substitution of labour or leisure between the members of a household. They likened a married woman to secondary workers of the household. Her labour supply and decision to participate in market production is a function of the expectation of the wage rate, the income received by her husband and her share of income not related to work. These authors distinguish the decision of time allocation by a woman from that of the man. The woman is traditionally the main producer of domestic services such as the minding and education of children and has minimum choices about remunerated employment. She must choose between remunerative work, domestic work and leisure for an optimum and balanced allocation of her time, using the market wage rate to assess the real cost of the marginal hour of domestic work. It is, therefore, the trade-off between these two rates that result in the woman's decision to participate in the labour market.

Lachaud (1993) conducted a comparative study based on a sample of six sub-Saharan African countries Burkina Faso, Cameroon, Côte D'Ivoire, Guinea, Madagascar and Mali. They indicate that the decision to participate in the labour market for market women is positively related to age and the level of schooling but negatively related to the income of other members of the household if leisure is a normal good having a positive income elasticity. They also argued that the mode of employment of the head of the household is an important determinant of the social relationships that shape the environment of labour, particularly the process of access to employment. They concluded that female labour supply in Africa is much lower than that of men, especially where the incidence of traditional structure is high.

In Nigeria, the decision for women to take employment is influenced by several socioeconomic, demographic and institutional variables such as family structure, husband's education, labour market conditions and other environmental variables (Okojie 1981; Urama and Obinna 2003).

\subsection{Theoretical Framework}

There is no consensus in the literature as to which model to use for modelling intra-household resource allocation from which women labour supply functions (whether to work and how much to work for pay in the market place) can be generated. For the purpose of this study we choose a collective model in which the household objective function is represented by joint utility maximization subject to budget and time constraint.

Assume a household consisting of two adult members, male (m) and female (f). Let each member's welfare be represented by a well-behaved quasi-concave household utility function of the form:

$U_{i}=U_{i}\left(Q_{i}, H_{i}, l_{f}, l_{m}\right)$

$\mathrm{Q}=$ vector of market goods and services consumed by household members

$\mathrm{H}=$ vector of non-market household-produced goods and services

$l_{i}=$ leisure time consumed by household members $i=m, f$

Each utility function represents the preferences of each member in the consumption of market and non-market goods and services.

Suppose the joint household social welfare $U=U\left(u_{f}, u_{m}\right)$ is a weighted average of the individual utility functions. A simple form of the function is:

$U_{i}=\lambda u_{f}+(1-\lambda) u_{m}, 0 \leq \lambda \leq 1$, (2)

where $\lambda$ denotes the relative weight given to the woman's preferences in the household's social welfare function.

The production technology for household-produced goods, denoted as $H$ and defined to include domestic activities such as food preparation, childcare, water and wood fuel collection, can be written as

$H=H\left(L_{m b}, L_{f l}, G ; F\right)$ 
where $L_{m h}$ and $L_{f h}$ are the time devoted to the production of $H$ by male and female, respectively. $G$ is a vector of market goods used as inputs in the production of $H$, and $F$ is a vector of technology parameters that affect efficiency in the production of $H$.

Let $Z$ represent the production of marketable output produced by the household. The implicit form of this production function is denoted by:

$Z=\mathrm{Z}\left(K, L_{m z}, L_{f z} * A ; J\right)$, with $Z>0$ if $K \geq K_{\min }$

$K$ is a vector of semi-fixed inputs used in $Z$ production, $L_{m z}$ the male's labour allocated to the production of $Z$, $L_{f z} *$ is the woman's labour in the production of $Z, A$ is a vector of variable inputs, and $J$ is a technology parameter that affects efficiency in the production of $Z$-good production. An example is information. Positive production requires a minimal level of semi-fixed input, e.g., capital. This restriction is implied by the constraint $\mathrm{K} \geq K_{\min }$. (5)

Further assume that $H$ and $Z$-goods are jointly produced, implying

$f_{z} *=L_{f z}+L_{f h}$

where $L_{i z}$ is the time spent exclusively on the production of $Z$.

The household's budget constraint is

$\mathrm{P}_{\mathrm{Q}} \mathrm{Q}+\mathrm{P}_{\mathrm{A}} \mathrm{A}+\mathrm{P}_{\mathrm{G}} \mathrm{G}+\varphi L_{f w}=W_{m} L_{m w}+W_{f} L_{f w}+P_{Z} Z+\mathrm{V}$ (7)

where $P_{j}\left({ }_{j}=Q, A, G, Z\right)$ is the price of $Q, A, G$ and $Z$, respectively; $W_{m}$ is the market wage of men's labour; $L_{m w}$ is men's time devoted to market wage income; $W_{f}$ is the market wage of women's labour; $L_{f w}$ is women's time devoted to market wage income; $\varphi$ is the transaction cost per unit of labour time of women workers owing to socioeconomic constraints; and $V$ is unearned income.

The time constraint for men is captured by

$L_{m}=L_{m w}+L_{m z}+L_{m h}+l_{m}$

and the time constraints for women is captured by

$L_{f}=L_{f w}+L_{f z}+L_{f h}+l_{f}, \quad(9)$

where $L_{m}$ is the total time available to men and $L_{f}$ is the total time available to women. Thus,

$L_{m}+L_{f}=T m \quad(10)$

Solving this constrained utility maximization problem (maximization of Equation 2 subject to the budget and time constraints and all other conditions presented above) and using the necessary conditions for optimization yield the labour supply function, which we specify in the next section and estimate in the later part of this study.

\section{Model Specification}

The model on labour force participation can be specified as:

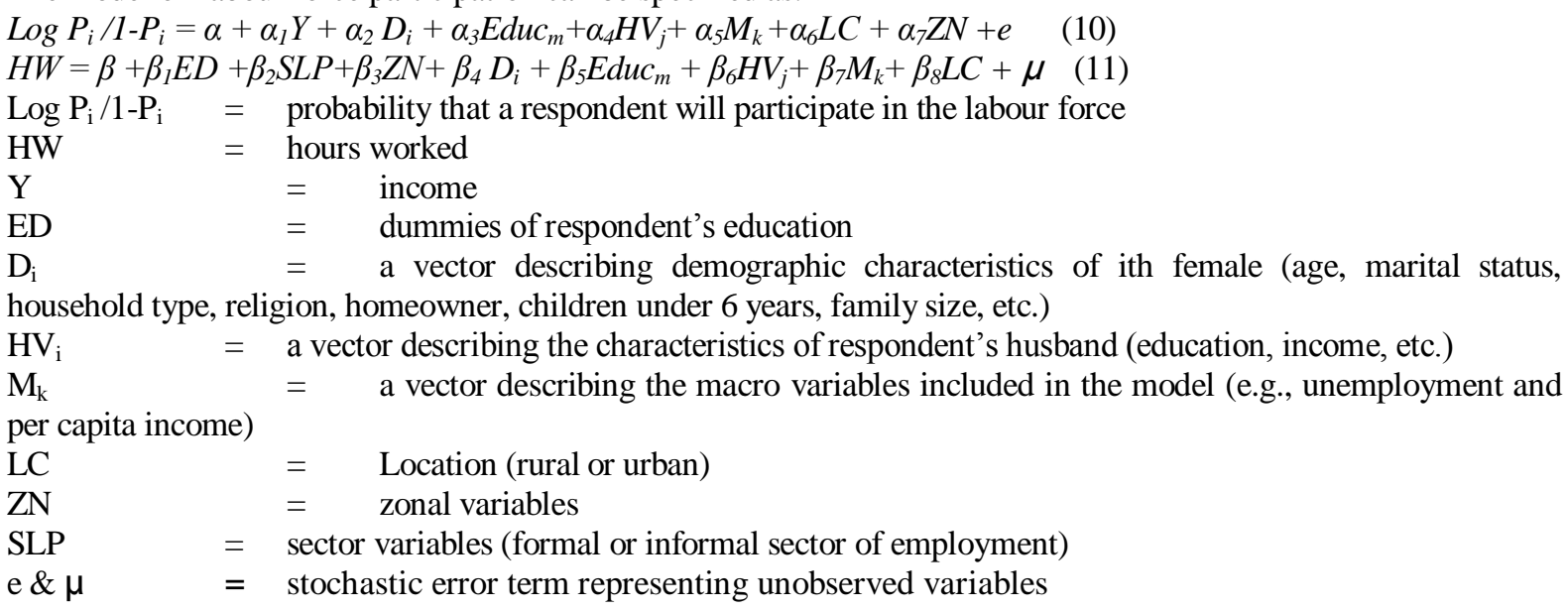

\section{Methodology}

The empirical work of this study is based on data collected in a survey designed and conducted from January to October 2001. Existing data on female employment in Nigeria are scanty and usually outdated. A survey was conducted to gather necessary information for the analysis. Macro data on unemployment and per capita income for the selected states for 1993 were included because the data for these two variables are only available for 1993.

A stratified multistage sample procedure was used to select the representative sample distributed over six states in Nigeria. The coverage of the study was limited to six states representing each of the geopolitical zones in Nigeria. The model was tested on a cross section of women aged 15 years and above. Table 1 provides summary statistics of the data. The enormous spatial diversity in the participation rates across the six 
geopolitical zones is evident in the available data that show the North-West zone with the lowest rate of 5.8\%, followed in ascending order by the North-East (35.9\%), North-Central (57.5\%), South-South (62.7\%), SouthEast (68.4\%) and South-West (76.02\%) (Federal Office of Statistics(FOS) 1996). The average female labour force participation is around $45 \%$. The stagnation in the participation rate of women in the labour market in the last three decades must be viewed against the significant shift in the structure of the labour force from dominance of the agricultural sector to services.

In the model specified for this study, two labour supply functions are estimated. One of the functions, labour force participation, is dichotomous, assuming two values 0 and 1 . The second function, the hours worked, is a quantitative variable that includes only those participating in the labour force. Since the decision to participate is endogenously determined, the estimate of labour supply may suffer from a sample selectivity bias. The dependent variable in the regression is the logarithm of the odds that a particular choice will be made. The logit model transforms the problem of predicting probabilities within $(0,1)$ interval to the problem of predicting the odds of an event occurring within the range of the real line (Greene 2000; Pindyck and Rubinfeld 1991).

If $P_{i}$ happens to equal either 0 or 1 , the odds $\left(P_{i} / l-P_{i}\right)$ will equal 0 or infinity and the logarithm of the odds will be undefined, thus, the application of the ordinary least square is inappropriate. This makes the logit estimation procedure imperative in this study. If the unmeasured characteristics influencing sample selection are jointly distributed, then the influence of selectivity bias associated with labour force participation can be substantially reduced by estimating the likelihood function of a probit model for all respondents in an equation of participation. This provides a consistent estimator such as an inverse Mill ratio, and this ratio is included in other equations (hours supplied and sector of participation) and ordinary least squares (OLS) applied to the resulting equation (Heckman 1974). Another problem associated with qualitative variable is the issue of the dummy variable trap. To avoid the problem, one of the dummies was dropped from each set of dummy variables (Greene 2000).

\section{Analysis Of Econometric Results}

Results presented below reflect the dual focus or this study - evidence of participation in the labour force, and evidence of hours worked. Tables 1-5 provide further elaboration of the findings.

\subsection{Empirical Evidence of Women's Labour Force Participation in Nigeria}

Table 4 shows the logistic regression results of labour force participation (LFP) of women by location, i.e., rural or urban. The results for reported age, education, ethnic origin, income, south east zone and per capita income are positively related with LFP for urban dwellers. On the other hand, LFP is inversely related to NorthCentral, North-West, religion, children under 6 and unemployment rate. Overall, age group groups 35-44 and $45+$, primary and tertiary education, respondent's income, North-West, South-East, Christianity, Islam, children under 6, per capita income, and unemployment are statistically significant at $1 \%$, while secondary level of education Yoruba and North-Central zone, are statistically significant at $10 \%$.

For rural dwellers, the dummies for education, relationship to household head (daughter) and respondent's income positively related to LFP, while family size (16+, North-Central zone and religion are negatively related. However, only tertiary education, household type, respondent's income, North-Central zone and religion are statistically significant at $1 \%$; secondary level of education is significant at $5 \%$ and relationship to household head (daughter) and family size (16+) are significant at $10 \%$ level.

There is need to exercise caution, however, because a straightforward interpretation, as it is done with multiple regression results, may be misleading. Thus, the results may not tell us much about the likelihood of a single variable influencing the participation in the labour force. Hence, we use odds ratios, which give the conditional probability of random responses falling into one of the categories of variables of interest.

Women aged 45 and above are more likely to participate in the labour force in the urban area compared with those aged 15-24. The results for education show that those with tertiary education are more likely to participate in the labour market than those with no education. Members of the Yoruba ethnic group are more likely than the Hausa to participate in labour market. The stronghold of the Islamic religion in the Hausa areas probably explains why most Hausa women are kept out of the job market.

Women from the South-East zone are more likely to participate in the labour market compared with those from the South-West. Women from the North-Central and North-West are less likely to participate in the labour force than those from the South-West. Per capita income has higher likelihood of affecting labour force participation by married women in the urban area compared with the unemployment rate.

\subsection{Rural-Urban Dimensions}

The level of income and per capita income positively influence the labour force participation of the non-married in the rural area and are statistically significant at $1 \%$, while secondary and tertiary level, of education negatively influence labour force participation for rural dwellers. Tertiary level of education is significant at 5\%, however, while secondary level of education is significant only at $10 \%$. Respondents without education (none) are more likely to participate in the labour force that those with other levels of education in the 
rural area. It could be inferred that the non-married from the rural area may not have been educated and therefore participate in the informal sector of employment; per capita income has a higher likelihood of influencing the participation of the non-married than the respondent's income.

In the urban area, the variables that influence the participation of the non-married in the labour force are age 15-24, household head, children under 6 and respondent's income. Household head and respondent's income positively influence the decision to participate significant at 1\%, while age 15-24 and children under 6 are negatively related to participation decision and significant at $1 \%$.

The results reveal that urban women aged $45+$ are more likely to be in the labour force than urban women aged 15-24. This may be because those in the younger age bracket are more likely to be in school. The non-married who are household heads in the urban area are more likely to participate in the labour force than the respondents who are daughters of the household head. This is probably because the household head is responsible for meeting the needs of the members of the household.

The respondents aged 15-24 in the rural area have greater likelihood of being in the labour force than those in the same age group in the urban area, again probably because of schooling for that age group in the urban area. Women with secondary and tertiary level of education in the urban area are more likely to participate in labour force than those with the same level of education in the rural area. This could be because the cost of living is higher in the urban areas for these categories of people because of their tastes and preferences, which would force them to participate in the labour force. In addition, such people might have gone to urban areas specifically in search of jobs.

The non-married in the urban area who are household heads are more likely to be in the labour market than those in the same category in the rural area. This could be due to the challenges of the high cost of living in the urban area. However, incomes have almost the same likelihood of affecting participation in both rural and urban areas. The Chi-squares of the model in the table are significant at $1 \%$, which signifies that overall the model is significant.

\subsection{Geopolitical Dimension}

Table 2 shows the logistic regression results for women by geopolitical zones. Here, combined variables were considered instead of dummies of the selected variables. Respondent's income, husband's income, children under 6, respondent's education and husband's education in years of schooling were considered. The logistic coefficients of income are positive in all zones and significant at $1 \%$. The coefficient for husband's income is negative and significant only in the North-East zone. Husband's education is negative and significant at $5 \%$ only in the South-West, while respondent's education is negative in the South-West and North-East zones and significant at $1 \%$. The presence of small children under 6 years old is negative and significant at $1 \%$.

The marginal effects are presented in Table 3 for all women by geopolitical zones. The marginal effects of the variables are computed on the basis of the respective logit coefficients and the sample mean of the variables. The statistics in the table show the impact of respondent's income, husband's income, husband's education, children under 6 and respondent's education on LFP. Respondent's income has the largest impact in North-Central, followed by South-South, while husband's income has the largest impact in South-South followed by North-East. In the case of the husband's education and respondent's education, the effect was highest in the South-West and followed by North-Central. The effect of children under 6 was highest in the North-East followed by the North-West; its effect in the South-East is rather weak.

\subsection{The Determinant of Hours Worked by Women}

Table 5 presents the result of the hours worked by women in Nigeria. The estimation in this section was done with a Heckman two-stage procedure. To carry out this estimation, a probit model was estimated for all samples for LFP where the dependent variable is one or zero depending on whether the respondent participated in the labour market or not. This provided a consistent estimator such as an inverse Mills ratio. The Mills ratio estimate was included with the subsample (working women only to correct for sample selectivity bias).

The result for hours worked by women in Nigeria shows that household head (daughter) informal employment, education (tertiary) and North-West zone are negatively correlated with married women's time. Family size (11-15 members) and urban location positively influence the magnitude of hours supplied by women. Those functions were estimated for working women only.

For family size (11-15), the positive coefficients for the married indicates that as family size rises, hours worked will increase. This indicates that a large family will be expensive to maintain, thereby requiring more income, which will induce the respondents to supply more hours of work for survival. Relationship with household head (daughter) is negative and conforms to the a priori expectation for daughter because of the possibility of depending on the household head for survival. Tertiary level of education is negatively correlated 
with hours worked and is significant. This indicates that the higher the level of education, the greater the likelihood for the respondent to be in the formal sector of employment where the hours of work are fixed and relatively fewer compared with the informal sector. Those with low level of education are likely to be in the informal sector where the hours supplied will be higher. This is consistent with the theory of labour supply because a higher level of education will command a higher income, which reduces the hour supply as income rises further (backward bending labour supply curve). The negative sign of the coefficient of the North-West zone signifies the attitude of married women in that zone to intensity of labour supply. Those in the labour force spend fewer hours at work.

The variables that are negatively related to hours worked for the non-married include education (tertiary) and location (urban). Tertiary education is significant at 5\%, while urban is significant at $10 \%$. However, income is positively related to hours worked and significant at $1 \%$. The positive sign for income indicates that high income will induce the non-married to supply more hours of work because of less responsibility for home production by this category. In addition, the higher-income women are more likely to be educated and in the formal sector with higher positions and levels of responsibilities, and more hours of work offered.

The negative coefficient of tertiary level of education conforms to a priori expectations and indicates that those with tertiary education are likely to work in the formal sector and that hours worked are fewer in the formal sector of employment compared with the hours of work in the informal sector. Location (urban) is negatively correlated to hours worked for non-married women.

The negative sign of Mill's ratio for the married indicates that the time spent in the labour force reduces the time allocated to home production and its significance highlights the importance of controlling for endogenous participation in the labour force to produce an unbiased estimation of the equation. The positive sign of the Mill's Ratio for the non-married indicates that they may not be hindered by household chores.

\section{Concluding Remarks}

Three main observations emerge from our analysis. First, there are diverse factors that influence women labour force participation in rural and urban locations in the economy. Education and ethnic origin influence participation in rural areas, while age, family size and unemployment rate have greater likelihood of influencing participation in the urban area for married women. For the unmarried in rural areas, age and ethnic group are more likely to influence participation, while relationship with the household head and religion have a greater likelihood to influence participation by urban women. The implication of this is that the rural-urban dichotomy should be taken into consideration in policies intended to influence labour force participation of women in Nigeria.

Second, reduction of overall unemployment rates will likely have the effect of drawing more women into the market, and policies to improve the conditions in the labour market will go a long way towards increasing female labour force participation.

Third, an increase in women's income, relative to that of men, would raise women's labour force participation rates in the North-Central, South-South and South-East, other things being equal. Furthermore, women's labour force participation appears to be sensitive to husband's education in the South-West. Children under 6 years have an impact on labour force participation in South-South, North-West and North-East zones. Women's education influences participation in the South-West and North-East zones. For all zones combined, all variables except husband's education has significant impact on labour force participation. In conclusion, policies intended to influence labour force participation should internalize these zonal and cultural differences with a focus on those factors that have higher impact labour participation in each zone.

[1] World Bank, World Development Indicators database, 2002

\section{References}

[2] Olusoji, M.O. Determinants of women labour force participation in Nigeria: Empirical evidence from the geopolitical zone. Doctoral thesis, Department of Economics, University of Ibadan, Nigeria. 2004

[3] Okojie, C.E.E. An economic analysis of women labour supply in Nigeria: A case study of Benin city. Doctoral thesis, Department of Economics, University of Ibadan, Nigeria. 1981

[4] Urama, K.C. and O.E Obinna, The economics of female labour supply: Theory and evidence from Nigeria. Final report. AERC Biannual Research Workshop. Nairobi, Kenya. 29th November - 5th December 2003.

[5] Singh, I; L Squire \& J. Strauss,. Agricultural Household Models: Extensions, Applications, and Policy. Baltimore, Md: John Hopkins University Press. 1986

[6] Haddad, L; J. Hoddinott and H. Alderman (ed), Intra Household Resource Allocation in developing Countries: Models, Methods and Policy. Baltimore: The Johns Hopkins University Press.. (1997)

[7] Joll, C., R. McNabb and J. Shorey. Developments in Labour Market Analysis. Georges Allen and Unwin. 1993.

[8] Lachaud, J .P ,Poverty and the urban labour market in sub-Saharan Africa: a comparative analysis, Discussion Paper No. 55.IILS Geneva. 1993.

[9] Federal Office of Statistics, Socio-Economic Profile of Nigeria. Abuja, Nigeria.1996

[10] Greene, W.H, Econometric Analysis, Fourth Edition. New York: Prentice Hall. 2000

[11] Pyndyck, R.S and D.L. Rubinfeld, Econometric Models and Economic Forecasts, Third Edition. New York: McGraw Hill. 1991

[12] Heckman, J., "Sample bias as a specification error". Econometrica, 42(1): 153-62.1975 
TABLE 1: Summary Statistics of Selected Variables for Respondents

\begin{tabular}{|l|r|r|r|r|r|r|r|r|}
\hline Variable & \multicolumn{2}{|c|}{ SW } & \multicolumn{2}{|c|}{ SE } & \multicolumn{2}{|c|}{ SS } & \multicolumn{2}{|c|}{ NC } \\
\hline & Mean & SD & Mean & SD & Mean & SD & Mean & SD \\
\hline $\begin{array}{l}\text { Respondent's } \\
\text { income* }\end{array}$ & $9,385.7$ & $8,831.6$ & $11,490.3$ & $9,300.6$ & $132,74.3$ & $13,685.3$ & $8,830.5$ & $11,304.1$ \\
\hline Husband's income* & $14,383.6$ & $69,367.8$ & $10,673.7$ & $13,611.2$ & $118,23.3$ & $21,911.1$ & $12,971.7$ & $14,921.1$ \\
\hline $\begin{array}{l}\text { Husband's } \\
\text { education** }\end{array}$ & 14.5 & 3.8 & 11.8 & 4.2 & 12.46 & 3.9 & 11.45 & 5.2 \\
\hline Under 6*** & 2.06 & 0.8 & 1.79 & 1.1 & 1.76 & 0.9 & 2.05 & 0.9 \\
\hline Education** & 14.17 & 2.9 & 12.27 & 4.2 & 12.36 & 3.0 & 11.57 & 4.1 \\
\hline
\end{tabular}

\begin{tabular}{|l|r|r|r|r|r|r|}
\hline Variable & \multicolumn{2}{|c|}{ NW } & \multicolumn{2}{|c|}{ NE } & \multicolumn{2}{|c|}{ All } \\
\hline & Mean & SD & Mean & SD & Mean & SD \\
\hline $\begin{array}{l}\text { Respondent's } \\
\text { income* }\end{array}$ & $8,101.7$ & $7,032.2$ & $7,053.6$ & $6,134.4$ & $5,544.3$ & $10,143.8$ \\
\hline $\begin{array}{l}\text { Husband's income* } \\
\text { Husband's } \\
\text { education** }\end{array}$ & $6,996.6$ & $11,876.7$ & $9,750.1$ & $11,106.0$ & $9,860.9$ & $35,911.9$ \\
\hline $\begin{array}{l}\text { Under 6*** } \\
\text { Education** }\end{array}$ & 9.2 & 7.0 & 9.24 & 5.8 & 11.47 & 5.4 \\
\hline \multicolumn{1}{|l|}{ In nara } & 9.6 & 2.21 & 0.9 & 2.06 & 0.9 \\
\hline
\end{tabular}

** $\quad$ Number of years of education

*** Number of children under the age of six in the household

Source: Olusoji (2004).

TABLE 2: Logistic Regression Result: Labour Force Participation of Women, by Geopolitical Zones (coefficient of selected variables with $\mathrm{Z}$-statistics in parentheses)

\begin{tabular}{|c|c|c|c|c|c|c|c|}
\hline Variable & SE & SS & SW & $\mathrm{NC}$ & NW & NE & All zones \\
\hline \multirow[t]{2}{*}{ Respondent's income } & $0.0016 *$ & $0.0032 *$ & $0.0004 *$ & 0.0119 & $0.00007 *$ & $0.0024 *$ & $0.0009 *$ \\
\hline & -5.59 & -3.2 & -5.56 & $(2.191) *$ & -9.19 & -8.46 & -18.38 \\
\hline \multirow[t]{2}{*}{ Husband's income } & 0.000006 & -0.00002 & 0.000001 & 0.00003 & -0.0002 & $-0.0001 *$ & $-0.000005 *$ \\
\hline & $(-0.26)$ & $(-1.18)$ & $(-0.23)$ & $((0.70)$ & $(-1.12)$ & $(-2.45)$ & $(-1.99)$ \\
\hline \multirow[t]{2}{*}{ Husband's education } & -0.0052 & 0.0078 & $-0.0112 * *$ & -0.0171 & -0.0005 & -0.0085 & -0.0019 \\
\hline & $(-0.84)$ & -1.23 & $(-2.15)$ & $(-1.43)$ & $(-0.09)$ & $(-1.29)$ & $(-0.90)$ \\
\hline \multirow{2}{*}{$\begin{array}{l}\text { Respondent's } \\
\text { education }\end{array}$} & -0.0021 & 0.0013 & $-0.0174 *$ & 0.0104 & -0.0061 & $-0.0103 *$ & $-0.0059 *$ \\
\hline & $(-0.27)$ & -0.19 & $(-2.79)$ & -1.56 & $(-1.71)$ & $(-1.89)$ & $(-3.29)$ \\
\hline \multirow[t]{2}{*}{ Children under 6} & -0.0922 & $-0.3017 *$ & -0.122 & 0.1567 & $-0.1372 *$ & $-0.3322 *$ & $-0.1495 *$ \\
\hline & $(-1.27)$ & $(-3.92)$ & $(-1.83)$ & -1.07 & $(-1.9)$ & $(-3.47)$ & $(-5.52)$ \\
\hline \multirow[t]{2}{*}{ Constant } & $-2.2196 *$ & $-3.07 *$ & $1.8171 *$ & $-15.0786 *$ & $-1.4298 *$ & $-2.3754 *$ & $-1.3567 *$ \\
\hline & $(-4.52)$ & $(-2.85)$ & -4.24 & $(-2.7)$ & $(-3.8)$ & $(-3.95)$ & $(-9.05)$ \\
\hline $\mathrm{N}$ & 439 & 415 & 371 & 473 & 444 & 493 & 2626 \\
\hline $\mathrm{R}^{2}$ & 0.62 & 0.61 & 0.33 & 0.85 & 0.43 & 0.72 & 0.55 \\
\hline LR $\operatorname{chi}^{2}(5)$ & 375.18* & $350.61 *$ & $108.23 *$ & $538.52 *$ & $247.76 *$ & 448.88* & $2002.97 *$ \\
\hline
\end{tabular}

\section{Notes:}

* Statistically significant at $1 \%$ or better

** Statistically significant at $5 \%$ or better

$\mathrm{N}=\quad$ Number of observations

TABLE 3: Marginal Effects for Women, by Zones

\begin{tabular}{|c|c|c|c|c|c|c|c|}
\hline Variable & SW & SE & SS & NC & NW & NE & All \\
\hline Respondent's income & $-31,101.75$ & $-209,851.84$ & $-557,970.42$ & $-930,683.57$ & $-40,394.92$ & $-119,191.94$ & $-30,171.29$ \\
\hline Husband's income & -206.05 & 691.48 & 22085.02 & -4206.30 & 1042.54 & 9752.61 & 504.61 \\
\hline Husband's education & 2.30 & 0.66 & -1.12 & 2.04 & 0.03 & 0.65 & 0.23 \\
\hline Education & 3.25 & 0.29 & -0.19 & -1.27 & 0.51 & 1.07 & 0.75 \\
\hline Children under 6 & 0.27 & 0.13 & 0.40 & -0.34 & 0.43 & 0.86 & 0.33 \\
\hline
\end{tabular}


Note: A given marginal effect is calculated as $b p(1-p)$, where $b$ is the respective logit coefficient from Table 2 and $\mathrm{P}$ is the respective sample mean participation rate (Fosu, 2000 )

*Logit coefficient on which estimate is based is significant at $1 \%$ or better.

TABLE 4: Logistic Regression Results: Labour Force Participation of Women, by Location (Zstatistics in parentheses)

\begin{tabular}{|c|c|c|c|c|}
\hline \multirow[t]{2}{*}{ Variable } & \multicolumn{2}{|c|}{ Married } & \multicolumn{2}{|c|}{ Non-married } \\
\hline & Rural & Urban & Rural & Urban \\
\hline \multicolumn{5}{|l|}{ Age } \\
\hline \multirow[t]{2}{*}{$15-24$} & - & - & 3.41 & -1.75 \\
\hline & & & $(0.32)$ & $(-1.82)^{* * *}$ \\
\hline \multirow[t]{2}{*}{$25-34$} & 0.25 & 0.93 & 6.03 & -0.07 \\
\hline & $(0.44)$ & $(0.26)$ & $(0.56)$ & $(-0.07)$ \\
\hline \multirow[t]{2}{*}{$35-44$} & 0.39 & $1.25^{*}$ & 1.05 & -1.19 \\
\hline & $(0.62)$ & $(3.22)$ & $(0.05)$ & $(-0.70)$ \\
\hline \multirow[t]{2}{*}{$45+$} & 1.12 & $1.34 *$ & - & - \\
\hline & (1.53) & (3.0) & & \\
\hline \multicolumn{5}{|l|}{ Education } \\
\hline None & - & - & - & - \\
\hline \multirow{2}{*}{ Primary } & 0.62 & $0.94 *$ & -0.86 & -0.19 \\
\hline & $(1.17)$ & (2.60) & $(-0.56)$ & $(-0.17)$ \\
\hline \multirow[t]{2}{*}{ Secondary } & $1.38 * *$ & $0.64 * * *$ & $-2.52 * * *$ & -0.64 \\
\hline & $(2.25)$ & $(1.77)$ & $(-1.94)$ & $(-0.85)$ \\
\hline \multirow[t]{2}{*}{ Tertiary } & $2.28 *$ & $1.73^{*}$ & $-4.29 * *$ & 0.18 \\
\hline & (2.59) & $(4.08)$ & $(-2.3)$ & $(0.22)$ \\
\hline \multicolumn{5}{|l|}{ Ethnic origin } \\
\hline \multicolumn{5}{|l|}{ Hausa } \\
\hline \multirow[t]{2}{*}{ Igbo } & 0.98 & 0.65 & 1.72 & 0.06 \\
\hline & (1.16) & $(1.28)$ & $(1.22)$ & $(0.07)$ \\
\hline \multirow[t]{2}{*}{ Yoruba } & 0.33 & $0.85^{* * * *}$ & -10.29 & 0.38 \\
\hline & $(0.37)$ & (1.70) & $(-0.01)$ & $(0.39)$ \\
\hline \multirow[t]{2}{*}{ Other } & 0.33 & 0.79 & 2.44 & 0.75 \\
\hline & $(0.37)$ & $(0.22)$ & (1.36) & $(0.84)$ \\
\hline \multicolumn{5}{|c|}{ Relationship to household head } \\
\hline \multirow[t]{2}{*}{ Head } & - & - & 0.58 & 2.6 \\
\hline & & & $(0.34)$ & $(3.17)^{*}$ \\
\hline \multirow[t]{2}{*}{ Wife } & 0.34 & 0.46 & - & - \\
\hline & $(0.40)$ & $(0.98)$ & & \\
\hline \multirow[t]{2}{*}{ Daughter } & - & -0.23 & - & - \\
\hline & & $(-0.28)$ & & \\
\hline \multirow[t]{2}{*}{ Maid } & $2.46^{* * *}$ & 0.79 & 0.93 & 1.21 \\
\hline & (1.67) & $(0.27)$ & $(0.57)$ & (1.03) \\
\hline Other & -0.56 & 2.52 & 1.20 & 1.28 \\
\hline & $(-0.04)$ & (1.78) & $(0.77)$ & (1.47) \\
\hline Marriage type & & & & \\
\hline Monogamy & - & & - & - \\
\hline Polygamy & 0.37 & -0.22 & - & - \\
\hline & $(0.65)$ & $(-0.64)$ & & \\
\hline Household ty & & & & \\
\hline Nuclear & - & - & - & - \\
\hline Extended & $1.30^{*}$ & -0.35 & -0.60 & -0.21 \\
\hline & (2.47) & $(-1.07)$ & $(-0.58)$ & $(-0.04)$ \\
\hline Family size & & & & \\
\hline $1-5$ & - & - & - & - \\
\hline $6-10$ & -0.22 & 0.40 & -0.70 & 0.39 \\
\hline & $(-0.52)$ & (1.46) & $(-0.79)$ & $(0.74)$ \\
\hline
\end{tabular}




\begin{tabular}{|c|c|c|c|c|}
\hline \multirow[t]{2}{*}{ Variable } & \multicolumn{2}{|c|}{ Married } & \multicolumn{2}{|c|}{ Non-married } \\
\hline & Rural & Urban & Rural & Urban \\
\hline $11-15$ & -1.25 & 0.12 & -1.56 & 0.33 \\
\hline & $(-1.54)$ & $(0.24)$ & $(-0.79)$ & $(0.41)$ \\
\hline $16+$ & $-1.99 * * *$ & 0.64 & -2.92 & -0.08 \\
\hline & $(-1.85)$ & $(1.04)$ & $(-0.49)$ & $(-0.08)$ \\
\hline Husband's education & & & & \\
\hline None & - & - & - & - \\
\hline & 0.46 & 0.12 & & \\
\hline Primary & $(0.77)$ & $(0.29)$ & - & - \\
\hline & 0.03 & 0.16 & & \\
\hline Secondary & $(0.04)$ & $(0.33)$ & - & - \\
\hline & -0.02 & 0.22 & & \\
\hline Tertiary & $(-0.03)$ & $(0.55)$ & - & - \\
\hline & 0.00002 & -0.0002 & & \\
\hline Husband's income & $(0.09)$ & $(-2.74)$ & - & 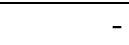 \\
\hline & -0.13 & -0.08 & & \\
\hline Home ownership & $(-0.70)$ & $(-0.83)$ & - & - \\
\hline & $0.0009^{*}$ & $0.0009^{*}$ & & \\
\hline Respondent's income & $(7.20)$ & (11.11) & 0.002 & 0.002 \\
\hline & -0.04 & 0.11 & $(4.25)^{*}$ & $(6.57)^{*}$ \\
\hline Domestic help & $(0.28)$ & (1.63) & - & 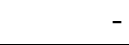 \\
\hline Zones & & & & \\
\hline South-West & - & - & - & - \\
\hline North-Central & $-6.8^{*}$ & $-1.05^{* * *}$ & -42.29 & -2.44 \\
\hline & $(-5.02)$ & $\begin{array}{l}(-1.82) \\
\end{array}$ & $(-0.05)$ & $(-0.99)$ \\
\hline North-West & -5.56 & $-3.55^{*}$ & -51.09 & -12.5 \\
\hline & $(-0.52)$ & $(-4.12)$ & $(-0.06)$ & $(-0.67)$ \\
\hline South-South & -51.4 & -0.51 & -213.07 & -2.27 \\
\hline & & $(-0.29)$ & $(-0.14)$ & $(-0.21)$ \\
\hline South-East & -24.85 & $6.73 *$ & -4.23 & 42.28 \\
\hline & $(-0.54)$ & $(2.94)$ & $(-0.005)$ & $(0.59)$ \\
\hline North-East & -4.98 & 0.16 & -10.02 & 8.73 \\
\hline & $(-0.50)$ & $(0.19)$ & $(-0.01)$ & $(0.49)$ \\
\hline Religion & & & & \\
\hline Christianity & $-16.1 *$ & $-7.24 *$ & - & 13.89 \\
\hline & $(-2.68)$ & $(-6.96)$ & & $(1.26)$ \\
\hline Islam & $-16.87 *$ & $-6.46^{*}$ & 0.51 & 14.17 \\
\hline & $(-2.82)$ & (-6.49) & $(0.41)$ & $(1.29)$ \\
\hline Traditional & - & - & - & - \\
\hline No. of children under 6 & -0.13 & $-0.10^{*}$ & 0.30 & -0.33 \\
\hline & $(-1.68)$ & $(-2.01)$ & $(1.22)$ & $(-2.92)$ \\
\hline Per capita income & 0.007 & $0.003 *$ & 0.06 & 0.02 \\
\hline & $(0.42)$ & $(2.62)$ & $(0.17)^{*}$ & $(0.59)$ \\
\hline Unemployment & 2.36 & $-1.28^{*}$ & -7.04 & -7.51 \\
\hline & $(0.33)$ & $(-3.27)$ & $(-0.22)$ & $(-0.60)$ \\
\hline $\mathrm{N}$ & 477 & 1035 & 251 & 615 \\
\hline $\mathrm{R}^{2}$ & 0.60 & 0.62 & 0.72 & 0.77 \\
\hline LR $\left(\mathrm{Chi}^{2}\right)$ & $373.27 *$ & $849.93 *$ & $211.02 *$ & $603.48^{*}$ \\
\hline
\end{tabular}


Women's Labour Supply in Nigeria: An Econometric Analysis

TABLE 5: Ordinary Least Square Estimate of Hours Worked by Women

\begin{tabular}{|c|c|c|c|c|}
\hline \multirow[t]{2}{*}{ Variable } & \multicolumn{2}{|r|}{ Married } & \multicolumn{2}{|c|}{ Non-married } \\
\hline & Coefficient & t-ratio & Coefficient & t-ratio \\
\hline Mills & -13.85 & $-1.81 * * *$ & 15.09 & 1.09 \\
\hline \multicolumn{5}{|l|}{ Age } \\
\hline $15-24$ & - & - & - & - \\
\hline $25-34$ & -7.56 & -0.72 & -12.35 & -0.99 \\
\hline $35-44$ & -23.26 & -2.13 & -7.40 & -0.33 \\
\hline $45+$ & -19.39 & -1.61 & -75.79 & -1.61 \\
\hline Respondent's income & 0.00025 & 0.83 & 0.0032 & $3.55^{*}$ \\
\hline Husband's income & $1.63 \mathrm{e}-06$ & 0.023 & - & - \\
\hline Home ownership & 0.32 & 0.26 & 10.60 & 1.61 \\
\hline \multicolumn{5}{|l|}{ Marriage type } \\
\hline Monogamy & - & - & - & - \\
\hline Polygamy & -3.77 & -0.45 & - & - \\
\hline No. of children under 6 & 0.90 & 0.85 & -8.81 & -1.31 \\
\hline \multicolumn{5}{|l|}{ Household type } \\
\hline Nuclear & - & - & - & - \\
\hline Extended & -3.65 & -0.49 & 2.46 & 0.17 \\
\hline \multicolumn{5}{|l|}{ Family size } \\
\hline $1-5$ & - & - & - & - \\
\hline $6-10$ & 9.88 & 1.63 & -10.56 & -0.72 \\
\hline $11-15$ & 39.46 & $3.14 *$ & 15.29 & 0.61 \\
\hline $16+$ & -2.59 & -0.18 & -14.17 & -0.53 \\
\hline \multicolumn{5}{|c|}{ Relationship to household head } \\
\hline Head & -5.42 & -0.53 & -3.02 & -0.12 \\
\hline Wife & - & - & - & - \\
\hline Daughter & -54.35 & $-2.64 *$ & -5.74 & -0.23 \\
\hline Maid & 57.26 & 0.92 & 61.29 & 1.12 \\
\hline Others & 21.32 & 0.62 & 49.62 & 1.48 \\
\hline Domestic help & -1.45 & -1.01 & 3.44 & 1.56 \\
\hline \multicolumn{5}{|l|}{ Sector of employment } \\
\hline Formal & - & - & - & - \\
\hline Informal & -4.72 & $-2.95 *$ & 0.20 & 0.09 \\
\hline \multicolumn{5}{|l|}{ Respondent's education } \\
\hline None & - & - & - & - \\
\hline Primary & -9.79 & -0.97 & -0.60 & -0.02 \\
\hline Secondary & -19.88 & -2.08 & -25.78 & -1.17 \\
\hline Tertiary & -50.79 & $-5.43 *$ & -57.58 & $-2.45 * *$ \\
\hline \multicolumn{5}{|l|}{ Husband's education } \\
\hline None & - & - & - & - \\
\hline Primary & 3.43 & 0.32 & - & - \\
\hline Secondary & -4.30 & -0.43 & - & - \\
\hline Tertiary & -6.26 & -0.69 & - & - \\
\hline \multicolumn{5}{|l|}{ Religion } \\
\hline Christianity & -43.71 & -0.76 & -22.71 & -1.33 \\
\hline Islam & -24.93 & -0.43 & - & - \\
\hline Traditional & - & - & - & - \\
\hline \multicolumn{5}{|l|}{ Location } \\
\hline Rural & - & - & - & - \\
\hline Urban & 23.57 & $3.89 *$ & -23.26 & $-1.80 * * *$ \\
\hline \multicolumn{5}{|l|}{ Zones } \\
\hline North-Central & -0.81 & -0.08 & 645.63 & 1.16 \\
\hline North-West & -34.8 & $-2.14 * *$ & 777.81 & 1.11 \\
\hline South-South & 33.34 & 0.88 & 4551.82 & 1.17 \\
\hline South-East & 14.42 & 0.34 & -41.88 & -0.60 \\
\hline
\end{tabular}




\begin{tabular}{|l|r|r|r|r|}
\hline \multirow{2}{*}{ Variable } & \multicolumn{3}{|r|}{ Married } & \multicolumn{2}{r|}{ Non-married } \\
\cline { 2 - 5 } & Coefficient & t-ratio & Coefficient & t-ratio \\
\hline North-East & 2.69 & 0.18 & -41.79 & -0.59 \\
\hline Per capita income & -0.003 & -0.16 & -1.39 & -1.18 \\
\hline Unemployment & -0.21 & -0.17 & 132.65 & 1.20 \\
\hline Constant & 243.83 & & 1046.52 & \\
\hline N & 975 & & 268 & \\
\hline R2 & 0.1351 & & & 0.2226 \\
\hline F & $4.19^{*}$ & & & \\
\hline
\end{tabular}

Note: Mills is the inverse mill ratio estimated from probit model of participation

$* * * * * *$ Indicate statistical significance at $1 \%, 5 \%$ and $10 \%$, respectively.

\footnotetext{
${ }^{\mathrm{i}}$ Specific women-oriented initiatives in the last decade include: Better Life for Rural Women, Family Support Programme, Family Economic Advancement Programme, Poverty Alleviation Programme and the current National Poverty Alleviation Programme

ii The spatial diversity is evident in the available data, which show the North-West zone with 5.8\%, North-East 35.9\%, North-Central 57.5\%, South-South 62.7\%, South-East 68.4\% and South-West 76.02\% (FOS, 1996)

iii The two earlier studies (Okojie, 1981; Urama and Obinna, 2003) are deficient in a number of respects. The most significant is their highly limited coverage. Okojie, the pioneer in this area of research, covered only urban women in Benin City in south-central Nigeria, while the latter study covered only south-eastern Nigeria.
}

${ }^{\text {iv }}$ For more general discussion see Singh et al. (1986), and Haddad, Hoddinott and Alderman (1997). 